ISSN 1392-3196

Zemdirbyste-Agriculture, vol. 100, No. 1 (2013), p. 71-80

UDK 633.5:631.531:631.526.32 / DOI 10.13080/z-a.2013.100.010

\title{
Physical parameters of dew retted and water retted hemp (Cannabis sativa L.) fibres
}

\author{
Zofija JANKAUSKIENĖ, Elvyra GRUZDEVIENE் \\ Upyte Experimental Station, Lithuanian Research Centre for Agriculture and Forestry \\ Linininkų 3, Upytė, Panevėžys distr., Lithuania \\ E-mail:soja@upyte.lzi.lt
}

\begin{abstract}
Even small additions of hemp fibres to fabrics result in significantly higher surface resistance and increased heat sorption. The two major retting methods (dew retting and water retting) are used to extract fibbers for industrial uses. Both methods produce fibres of different quality.

The results of research, carried out at the Lithuanian Institute of Agriculture, Upyte Experimental Station in 20062007, showed that dew retted and water retted hemp fibres differed in appearance. Hemp variety as a factor showed higher impact on physical fibre parameters: fibre content in dew retted and water retted hemp straw, dew retted hemp straw output from hemp stalks, the strength of fibre obtained from dew retted and water retted hemp. Seed rate as a factor did not show any significant influence on physical fibre parameters, and only some trends of higher parameters at higher seed rates could be observed.

Statistical evaluation indicated that the year as a factor affected the majority of physical parameters tested. Statistical data processing also showed that the fibre extraction method as a factor had a significant influence on the fibre content in hemp straw in 2006, on the straw output from hemp stalks in 2007, on the fibre content in hemp stalks and hemp fibre flexibility in both years of investigation, on the hemp fibre strength in 2006.
\end{abstract}

Key words: Cannabis sativa, dew retting, fibre, physical indices, seed rate, variety, water retting.

\section{Introduction}

The applications of hemp fibres considerably vary and could range from apparel and ornamental fabrics to industrial materials. The long fibre from the stalks can be spun into threads, made into ropes, woven into fabrics, carpets and shoes and made into canvas (Mwaikambo, 2006). Even small additions of hemp fibres to fabrics result in significantly higher surface resistance and increased sorption heat. When wearing hemp clothes, a human body more easily adapts to changing environmental conditions. In the production of socks the properties of inhibiting bacterial and fungal development have practical importance (Mańkowski, 2003). Plant fibres are an excellent alternative resource to synthetic fibres as reinforcement for polymeric materials for the manufacture of cheap, renewable and environmentally friendly composites (Mwaikambo, 2006).

Hemp fibres are 1-3 cm long (Garcia-Jaldon et al., 1998), other resources report that the actual cells range from 5 to $55 \mathrm{~mm}$ in length (Bengtsson, 2009). Hemp bast fibres are situated in the bark of the plant (Garcia-Jaldon et al., 1998; Zhang et al., 2008). Parenchyma cells separate bundles of single fibres from one another. Between the single fibres, there are mainly polysaccharides and lignin, which must be eliminated to obtain fibres (Thygesen et al., 2005). To extract fibers for industrial uses, stems are retted to separate fiber from non-fiber stem issues. In this process, bast fiber bundles are separated from the core, epidermis, and cuticle and are also separated into smaller bundles (Sharma, 1987; Zhang et al., 2008).
Generally two retting methods (dew retting and water retting) have been used, both carried out by pectic enzymes secreted by indigenous microflora (Bengtsson, 2009; Mwaikambo, 2006; Zhang et al., 2008).

In dew retting, stalks are laid on the ground, and pectins are attacked by pectinolytic microorganisms, mainly aerobic fungi (Henriksson et al., 1997). Dew retting is most popular in Europe although it is strongly dependent on the geographical location, produces coarser and lower quality fibres than those produced using water retting technique (Van Sumare, 1992).

In water retting, stalks are soaked in freshwater tanks, where a pectinolytic bacterial community is developed (Donaghy et al., 1990). Water retting may require large amount of clean water and therefore is expensive but results in high quality fibres (Mwaikambo, 2006). Water retting was the valuable method of choice for many years because of high-quality fiber (Akin et al., 2001; Xu, 2010). In the mid-1990s water retting was mostly closed in western countries because of the contamination and consumption of the freshwater (Akin et al., 2001).

Currently, dew retting is the primary process used for the industrial production of bast fibers nevertheless water retting is still carried out in some places (Daenekindt, 2004).

The references show that the fibre content in hemp stem is dependent on genotype, plant density (seed rate) and development stage of the hemp at harvesting 
time, and other factors (Amaducci et al., 2005; Sankari, 2000). Higher bast fibre content in hemp stem is associated with higher plant density and thinner pants (Van der Werf et al., 1994; 1995; Cromack, 1998; Struik et al., 2000; Amaducci et al., 2005).

The economically optimal plant densities of hemp grown for fibre are higher than the lowest plant density that gives maximum stem dry matter yield because plant density continues to improve stem quality when it no longer increases stem yield. With increasing plant density, bast fibre content in the stem tends to increase and the fineness of the bast fibres improves (Van der Werf et al., 1995).

Some authors report that there was a strong negative correlation between the fibre content and the fibre quality (Bengtsson, 2009). Even a 1\% increase in fibre content reduced fibre fineness (Bócsa, 1999).

We found references that the strength of the long fibres, tow and even single fibre cells undergoes a wide variation, which depends on the weather during the growing season, soil type, fertilization and retting (Hoffmann, 1961). This is why we distinguished the year as a factor, containing the mentioned sub-factors.

The task of our investigation was to verify the hypothesis that higher fibre content and quality could be achieved at higher hemp seed rates (consequently, at higher crop densities), to investigate physical parameters of different fibre hemp varieties, and to compare the results of dew and water retting methods.

\section{Materials and methods}

Research was carried out at the Lithuanian Institute of Agriculture, Upyte Experimental Station in 2006-2007.

Field experiments. Hemp was grown on an Eutri-Endohypogleyic Cambisol (CMg-n-w-eu) (Buivydaite et al., 2001). In the field rotation hemp followed winter wheat. The content of available $\mathrm{P}_{2} \mathrm{O}_{5}$ in the soil plough layer was 275 and $202 \mathrm{mg} \mathrm{kg}^{-1}$ in 2006 and 2007, respectively; content of $\mathrm{K}_{2} \mathrm{O}-175$ and $128 \mathrm{mg} \mathrm{kg}^{-1}$ (determined in A-L extraction); $\mathrm{pH}_{\mathrm{KCl}}$ level - 7.3 and 7.5 (potentiometrically); humus content $-2.31 \%$ and $2.0 \%$ in 2006 and 2007, respectively (by Tyurin method).

The recommended sowing rates for fibre hemp vary between 40 and $150 \mathrm{~kg}$ per ha, which correspond to plant densities shortly after emergence of about 200 to 750 plants per $\mathrm{m}^{2}$ (Van der Werf et al., 1995). Fiber strains are typically sown at a minimum rate of 250 seeds per $\mathrm{m}^{2}$ (approximately $45 \mathrm{~kg} \mathrm{ha}^{-1}$ ), and up to three times this density is sometimes recommended. In Western Europe, seeding rates range from $60-70 \mathrm{~kg} \mathrm{ha}^{-1}$ for fiber cultivars (Small, Marcus, 2002). According to some references, the best seed rate when growing hemp for textile purposes is $70-80 \mathrm{~kg} \mathrm{ha}^{-1}$ (Bócsa, Karus, 1998) while other sources report on $75-80 \mathrm{~kg} \mathrm{ha}^{-1}$ or even $50-60$ $\mathrm{kg} \mathrm{ha}^{-1}$ (growing hemp for seed and fibre) (Svennerstedt, 2002; Grabowska, Koziara, 2005). A hemp seed rate of $90 \mathrm{~kg} \mathrm{ha}^{-1}$ gave too thin stalks (Svennerstedt, 2002). Research done in Poland indicated that the highest stalk and fibre yield was obtained when sowing hemp at a rate of $120 \mathrm{~kg} \mathrm{ha}^{-1}$, but the best fibre quality was found to be at a seed rate of $90 \mathrm{~kg} \mathrm{ha}^{-1}$ (Mańkowski, 2003).

$\mathrm{Bi}$-factorial trial was carried out: factor $\mathrm{A}$ - variety (A1 - 'Beniko', A2 - 'Bialobrzeskie'), factor B - sowing rate $\left(\mathrm{B} 1-40 \mathrm{~kg} \mathrm{ha}^{-1}, \mathrm{~B} 2-55 \mathrm{~kg} \mathrm{ha}^{-1}, \mathrm{~B} 3-70 \mathrm{~kg} \mathrm{ha}^{-1}\right)$. The both varieties are monoecious, of Polish origin.

Before sowing, the complex fertilisers $\left(\mathrm{N}_{12} \mathrm{P}_{16} \mathrm{~K}_{24}\right.$ and $\mathrm{N}_{25} \mathrm{P}_{9} \mathrm{~K}_{9}$ ) were applied for hemp trial background (total amount of active ingredient - N $148 \mathrm{~kg} \mathrm{ha}^{-1}, \mathrm{P} 76 \mathrm{~kg}$ $\left.\mathrm{ha}^{-1}, \mathrm{~K} 128 \mathrm{~kg} \mathrm{ha}^{-1}\right)$. Hemp was sown by a sowing machine SLN-1.6 "Bezhetskselmash" (Russia), in mid May in the plots of $10 \mathrm{~m}^{2}$ with three replications. Randomised plot design was used. Protective plots of the same size were sown on both sides of the trial. No pesticides (insecticides, herbicides, desiccants) were used.

Hemp was harvested in the middle of October by a trimmer (leaving the stubble of 5-8 cm) when the first matured seeds appeared. Hemp stalk samples from each plot were taken and dried.

Laboratory analyses. Before starting dew or water retting, technical stalk part from hemp stalks was prepared (cutting away the top part of plant containing panicle and leaves). One part of hemp stalk samples $(0.5$ $\mathrm{kg}$ per plot) was water retted (water temperature $37^{\circ} \mathrm{C}$ ) for 5 days, the other part $(0.5 \mathrm{~kg}$ per plot) was dew retted on the grassland for 2-3 weeks; then dry straw was weighed and broken by a laboratory tool LM-5 (VNIIL, All Russia Flax Research Institute), the obtained material was shaken manually until the shives were withdrawn. The obtained fibre was weighed and fibre content in the straw was calculated by the formula:

Fcstr $=$ Wf $\times 100 /$ Wstr, where: Fcstr - fibre content in the straw (\%), Wf - weight of obtained fibre (g), Wstr - weight of straw before scutching (g). calculated:

Then the straw output from hemp stalks was

Stro $=$ Wstr $\times 100 /$ Ws, where: Stro - straw output from hemp stalks (\%), Wstr - weight of straw before scutching (g), Ws - weight of stalks before retting $(\mathrm{g})$.

Later on fiber content in the stalks was recalculated:

$\mathrm{Fcs}=\mathrm{Wf} \times 100 / \mathrm{Ws}$, where: Fcs - fibre content in the stalks (\%), Wf - weight of obtained fibre (g), Ws weight of stalks before retting $(\mathrm{g})$.

Fibre flexibility was evaluated by a device G-2 (VNIIL, All Russia Flax Research Institute), strength of fibre was measured by a device DK-60 (CNII, Central Research Institute, Russia) (Методики..., 1961).

Meteorological conditions. The parameters of meteorological conditions (mean air temperature, ${ }^{\circ} \mathrm{C}$ and rainfall, $\mathrm{mm}$ ) were recorded by the weather station located in the trial field.

In 2006 and 2007, the period for hemp seed emergence was favourable, but in 2007 later on a lack of precipitation occurred ( $1^{\text {st }}$ ten-day period of June) (Figs 1 and 2). In 2006, the drought and warm weather were recorded in June, July, while in 2007 this period was much more abundant in rainfall. The rainfall in June and July is important as it strongly influences the yield (Bócsa, Karus, 1998). Since hemp roots grow deep, the plants are more tolerant of drought (Barron et al., 2003). The mean air temperature in August was very similar in both years, but the amount of rainfall differed markedly - in 2006 it was twice as high as the long term average, and in 2007 it was approximately twice as low as the long term average. In September and $1^{\text {st }}$ ten-day period of October the weather was still warm, later on it became cooler. Hemp dew retting period in 2006 was quite dry (not favourable) weather, in 2007 the amount of precipitation was higher, but the temperature was lower. 


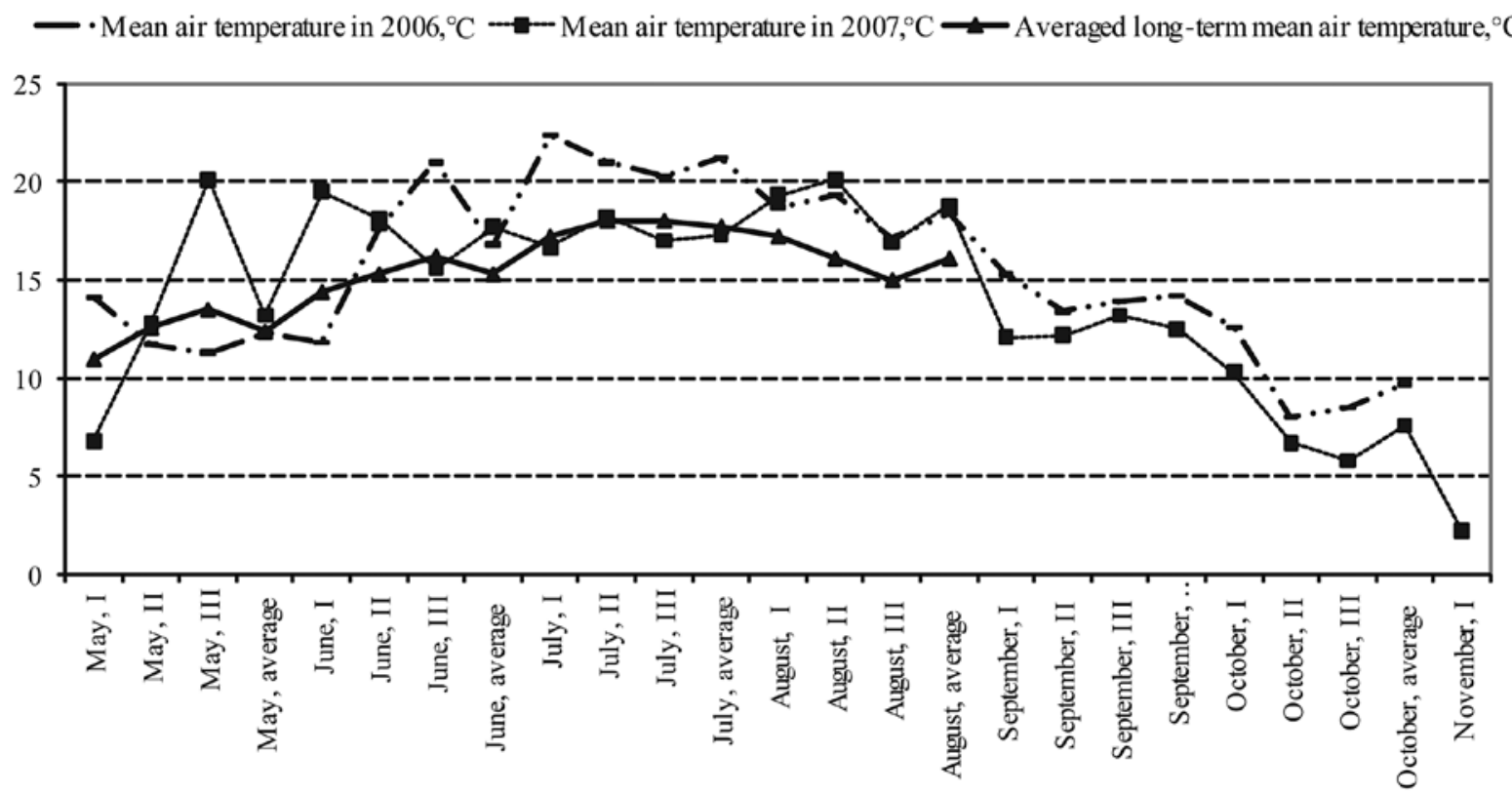

Upytė Experimental Station, 2006-2007

Figure 1. Mean air temperature during the hemp growing and dew retting season

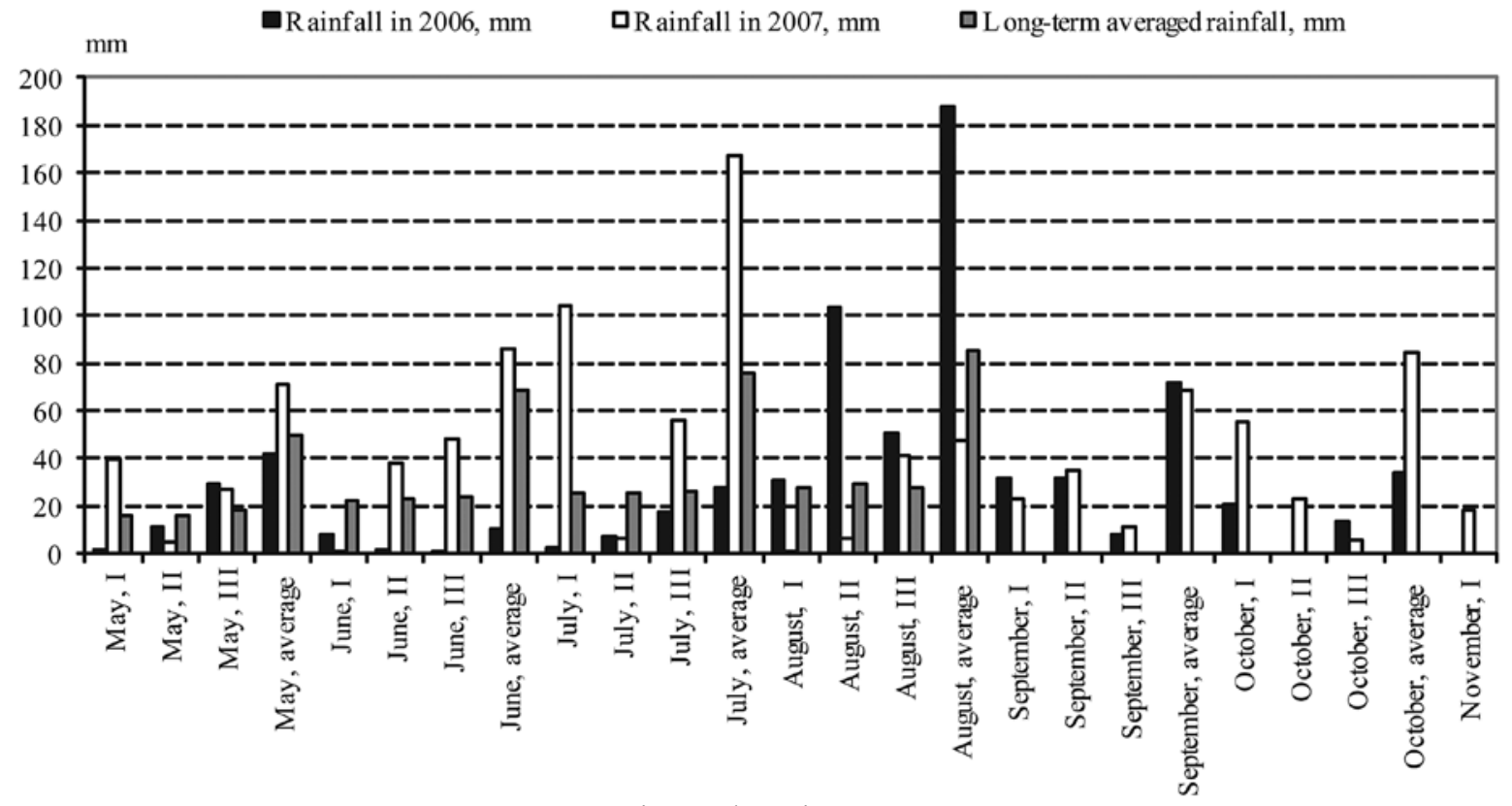

Upytė Experimental Station, 2006-2007

Figure 2. Rainfall during the hemp growing and dew retting season

Some authors have reported, that the layer of the primary fibre cells gets smaller from the beginning of flowering to full seed ripeness, and the layer of the secondary fibres becomes much bigger between the end of flowering and 50\% seed ripeness, and it is greatly influenced by the year (Garcia-Jaldon et al., 1998). In our trials, hemp started flowering at the end of July beginning of August, and flowered for a very long period, along with seed ripening. The hemp had different climatic conditions for fibre development in both years of investigation.
Statistical analysis. The statistical analyses were made using $A N O V A$ software from the statistical data processing package SELEKCIJA (Tarakanovas, Raudonius, 2003). Mainly two- or tree-way analysis was applied for statistical data processing.

\section{Results and discussion}

Biologically extracted (using dew retting and water retting) hemp fibres differed in appearance. After dew retting, the fibre (Fig. 3) was not very homogenous, 
had steel-grey and dark-grey colour, contained some dark spots (the residues of dew retting fungi), and included some impurities (woody parts of stem).

After water retting, hemp fibre (Fig. 4) also was not very homogenous, had light-grey colour, look softer

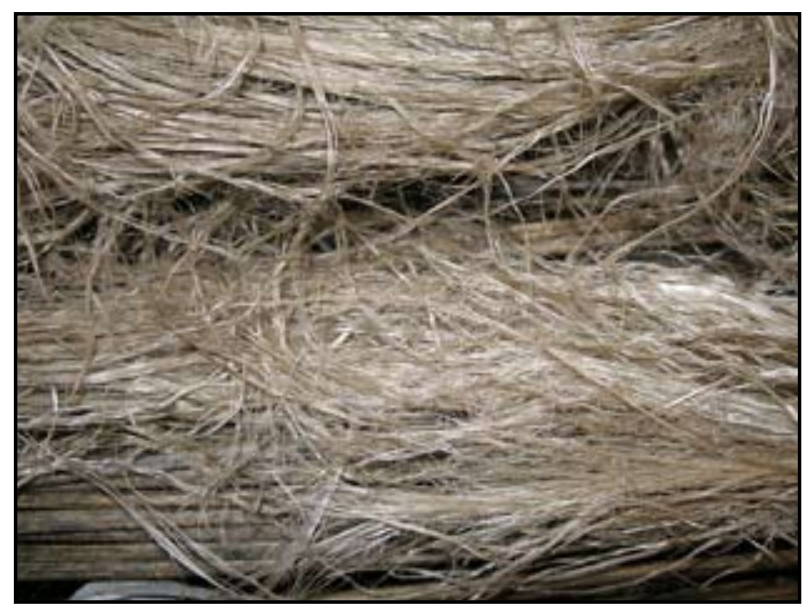

and more decomposed. Other researchers also found that water retting gave the best fibre quality when visually determining the quality parameters (length, colour and smoothness) (Bengtsson, 2009).

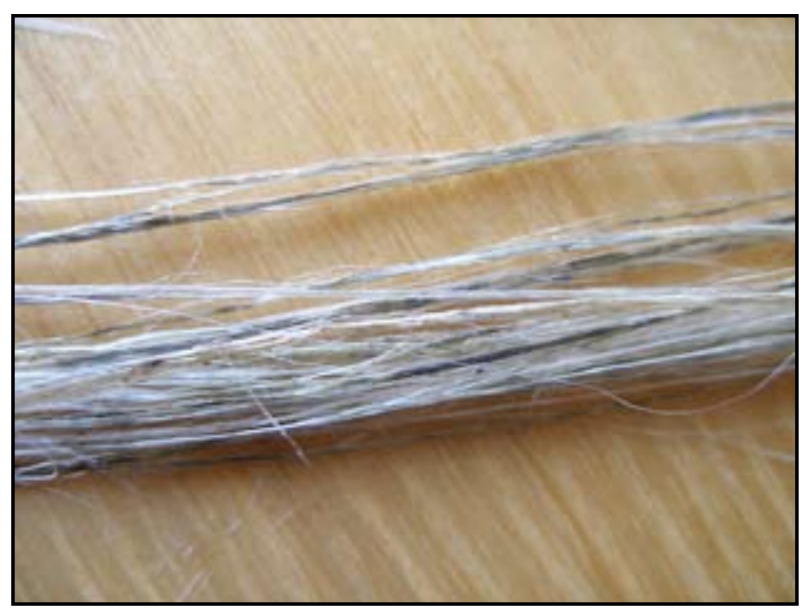

Figure 3. Dew retted hemp fibre after scutching (on the left) and after combing (on the right)
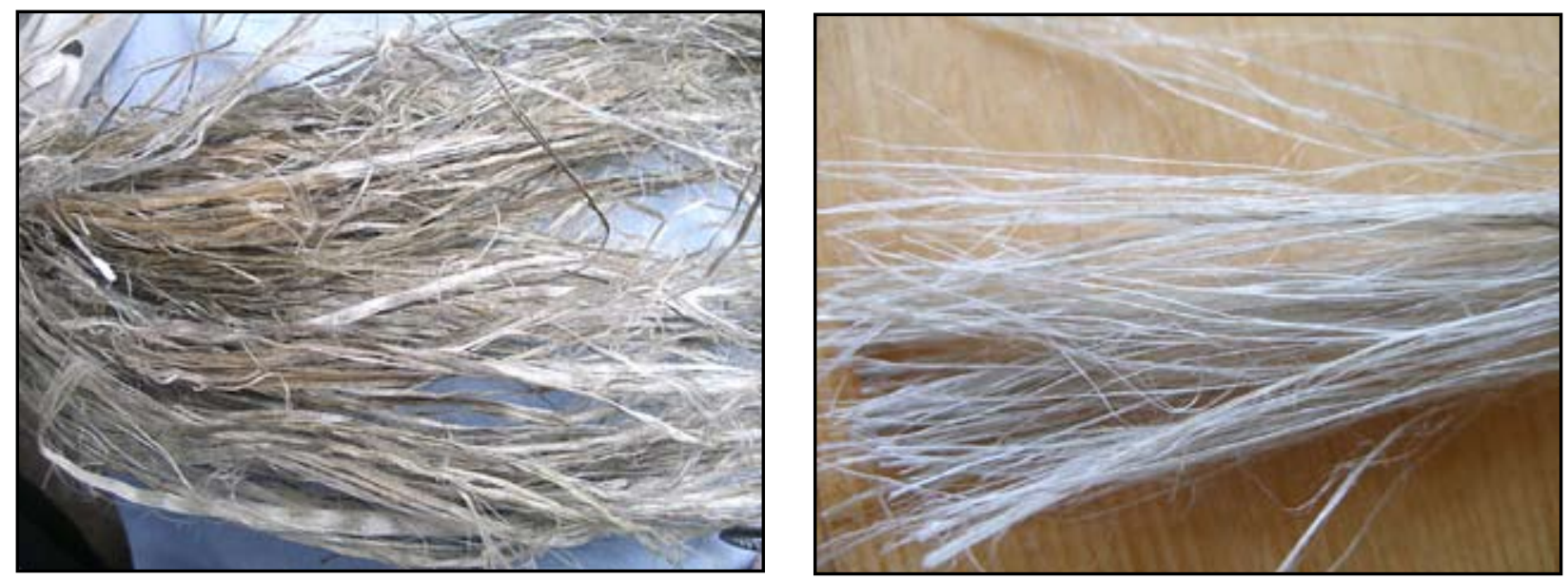

Figure 4. Water retted hemp fibre after scutching (on the left) and after combing (on the right)

Fibre content in hemp straw. Fibre content in dew retted hemp straw varied from $19.9 \%$ to $25.5 \%$ in different treatments in 2006 and from $23.5 \%$ to $29.2 \%$ in 2007. In both years of the investigation, an average fibre content of variety 'Beniko' showed a tendency to be higher than that of variety 'Bialobrzeskie', but only in 2007 the influence of variety as a factor was significant (Table 1). Seed rate as a factor did not exert any significant influence on the dew retted hemp fibre content in hemp straw. Nevertheless, a tendency of slightly lower fibre content at a seed rate of $55 \mathrm{~kg} \mathrm{ha}^{-1}$ for both varieties tested was observed in 2006. In the trials, carried out in Poland, where seed rate, $\mathrm{N}$ doses and harvesting time were investigated, seed rate also did not have any influence on fibre content in dew retted hemp sown at different seed rates $\left(60,90\right.$ and $\left.120 \mathrm{~kg} \mathrm{ha}^{-1}\right)$ (Mańkowski, 2003).

We presented the data of soil fertility and meteorological conditions in the Materials and methods section because this could be an important factor (later on discussed as the composite influence of the year as a factor) affecting the study results. Statistical evaluation showed that the year as a factor influenced the dew retted hemp fibre content in straw (the average fibre content in dew retted hemp straw in 2006 was $22.9 \%$ and in 2007 $-26.7 \%$ ), therefore the results averaged over two years cannot be presented. The same (three-factor analysis) calculation showed that the variety as a factor also had significant influence on the dew retted hemp fibre content in hemp straw; the average fibre content for variety 'Beniko' was $26.2 \%$ and for variety 'Bialobrzeskie' $-23.4 \%$.

The results of our investigation suggest that fibre content in water retted hemp straw was higher than that of dew retted hemp straw and varied from $30.1 \%$ to $36.3 \%$ in different treatments in 2006, and from $22.6 \%$ to $26.8 \%$ in 2007. In 2006, the influence of variety as a factor was significant (Table 2), an average fibre content of variety 'Beniko' was $34.4 \%$, and an average fibre content of variety 'Bialobrzeskie' was $30.8 \%$. Seed rate as a factor in both experimental years did not exert any significant influence on the water retted hemp fibre content in hemp straw; only in 2006 the tendency of insignificantly higher fibre content at higher seed rates could be observed. 
Table 1. The influence of variety and seed rate on the dew retted hemp fibre content (\%) in the straw Upyte Experimental Station, 2006-2007

\begin{tabular}{|c|c|c|c|c|}
\hline \multirow{2}{*}{$\begin{array}{c}\text { Variety } \\
\text { (factor A) }\end{array}$} & \multicolumn{3}{|c|}{ Seed rate (factor B) } & \multirow{2}{*}{ Average factor A } \\
\hline & $40 \mathrm{~kg} \mathrm{ha}^{-1}$ & $55 \mathrm{~kg} \mathrm{ha}^{-1}$ & $70 \mathrm{~kg} \mathrm{ha}^{-1}$ & \\
\hline \multicolumn{5}{|c|}{2006} \\
\hline 'Beniko' & 23.9 & 22.5 & 24.6 & 23.7 \\
\hline 'Bialobrzeskie' & 21.2 & 19.9 & 25.5 & 22.2 \\
\hline Average factor B & 22.6 & 21.2 & 25.0 & - \\
\hline \multicolumn{5}{|c|}{$\mathrm{LSD}_{05}($ variety $)=1.544$} \\
\hline \multicolumn{5}{|c|}{2007} \\
\hline 'Beniko' & 29.2 & 29.2 & 28.1 & $28.8 *$ \\
\hline 'Bialobrzeskie' & 26.0 & 23.5 & 24.1 & $24.6^{*}$ \\
\hline Average factor B & 27.6 & 26.3 & 26.1 & - \\
\hline $\mathrm{LSD}_{05}$ & $\mathrm{LSD}_{05}$ & 2.317 & $\times$ seed rate) & \\
\hline
\end{tabular}

* - significant at 0.05 probability level

Table 2. The influence of variety and seed rate on the water retted hemp fibre content (\%) in the straw Upyte Experimental Station, 2006-2007

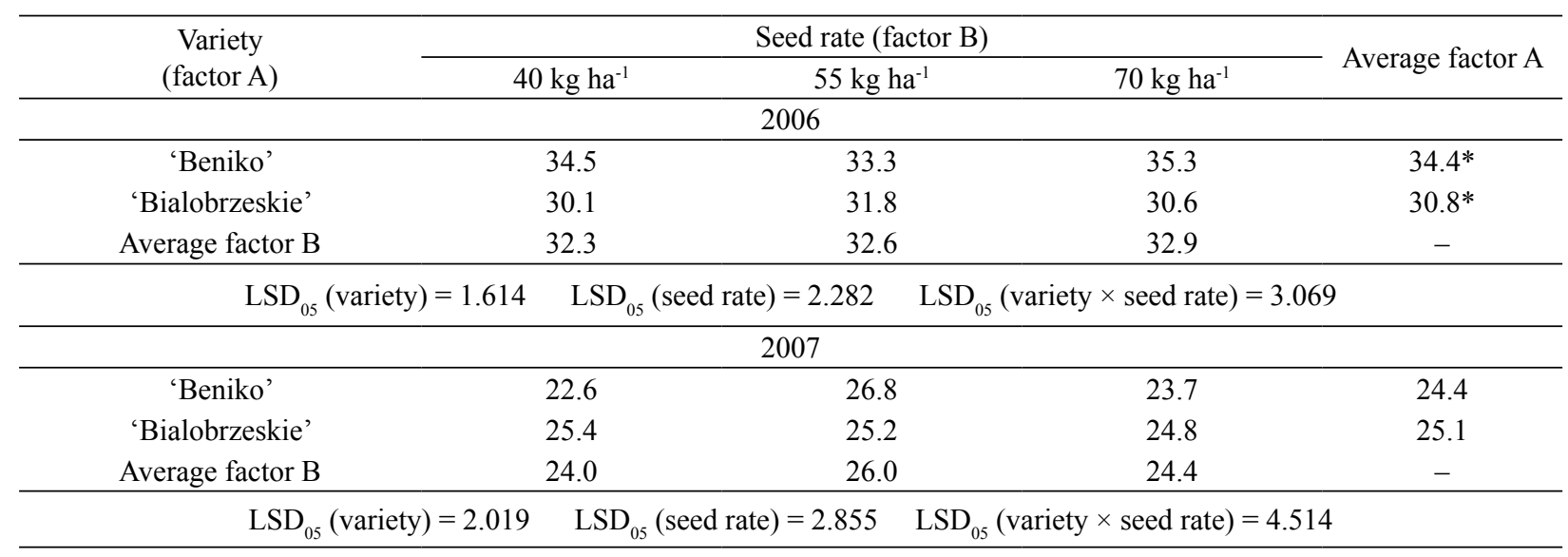

* - significant at 0.05 probability level

The influence of the year as a factor was also calculated. The calculation indicated that the year as a factor had significant influence on the water retted hemp fibre content in hemp straw (the average fibre content in water retted hemp straw in 2006 was $32.9 \%$ and in 2007 - 24.8\%), so the averaged data from 2006-2007 could not be presented.

Even with the naked eye we can see differences in the data of dew retted and water retted fibre content in hemp straw. We also calculated the influence of fibre extraction method (dew retting or water retting) as a factor on the data of fibre content in hemp straw. Calculation (threefactor analysis) showed that the fibre extraction method as a factor also had significant influence on the hemp fibre content in hemp straw in 2006 (in 2007 this influence was not significant). The average fibre content in dew retted hemp straw was higher after dew retting process; it was $32.6 \%$ while in water retted straw it was $24.8 \%$.

Hemp straw output from hemp stalks. Usually the stems of fibrous plants lose weight during the retting process. The data of hemp straw output from hemp stalks after dew retting or water retting process are not available in the literature sources.

The data from our investigation evidenced that dew retted hemp straw output from hemp stalks was influenced by the variety as a factor, but only in 2006 the differences were found to be significant (Table 3). Dew retted hemp straw output from hemp stalks ranged from $51.7 \%$ to $59.3 \%$ in 2006 and from $38.7 \%$ to $50.0 \%$ in 2007. Seed rate as a factor did not show any significant influence on the dew retted hemp straw output from hemp stalks.

Statistical evaluation showed that the year as a factor affected the dew retted hemp straw output from hemp stalks; therefore the results averaged over two years cannot be presented. The average hemp straw output from hemp stalks in 2006 was $56.1 \%$ and in $2007-46.4 \%$. The same (three-factor analysis) calculation showed that the variety as a factor also had significant influence on the dew retted hemp straw output from hemp stalks; the average straw output for variety 'Beniko' was $48.9 \%$ and for variety 'Bialobrzeskie' $-53.6 \%$.

Our experimental results show lower water retted hemp straw output from hemp stalks (Table 4) when compared to that of dew retted straw. Averaged water retted hemp straw output from hemp stalks varied in the range from $56.0 \%$ to $62.0 \%$ in 2006 and from $36.0 \%$ to $42.0 \%$ in 2007 . Neither variety (factor A) nor the seed rate (factor B) showed any significant influence on the water retted hemp straw output from hemp stalks, nevertheless the tendency of slightly higher straw output from hemp stalks for variety 'Beniko' could be observed. 
Table 3. The influence of variety and seed rate on the dew retted hemp straw output (\%) from the stalks Upytė Experimental Station, 2006-2007

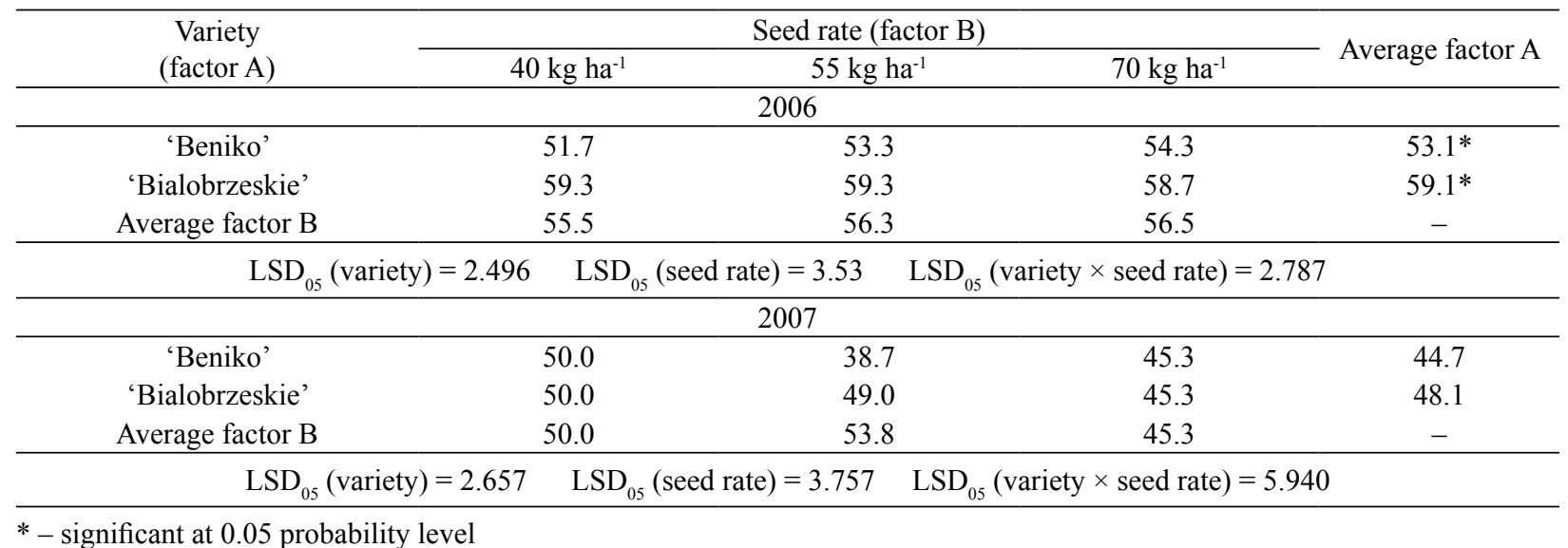

Table 4. The influence of variety and seed rate on the water retted hemp straw output (\%) from the stalks Upytė Experimental Station, 2006-2007

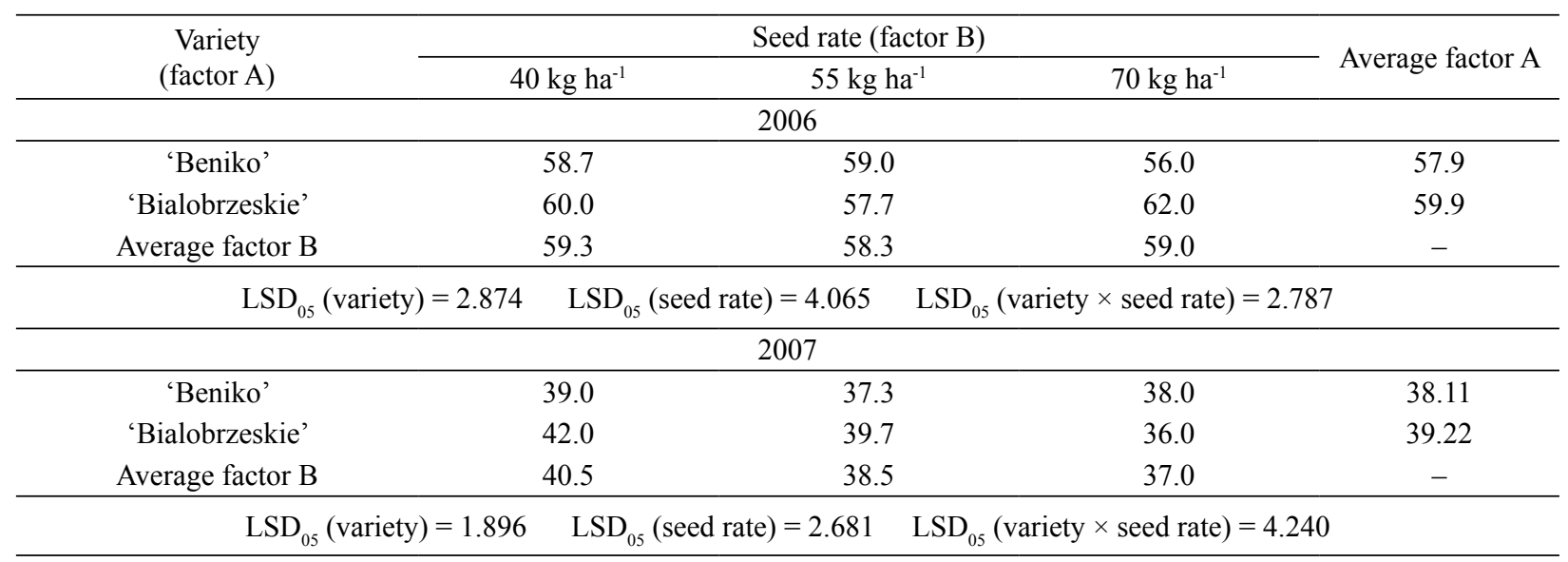

Statistical evaluation showed that the year as a factor affected water retted hemp straw output from hemp stalks; therefore, the results averaged over two years cannot be presented.

The influence of the fibre extraction method (dew retting and water retting) as a factor was also evaluated. Statistical processing of the data (three-factor analysis) indicated that fibre extraction method as a factor had a significant influence on the hemp straw output from hemp stalks only in 2007 . The average straw output from hemp stalks after dew retting was higher $(46.4 \%)$ than that of water retted straw $(38.7 \%)$.

Fibre content in hemp stalks. To be able to calculate fibre yield, we need to know fibre content in the stalks. It is possible to calculate it from the data of fibre content in the straw and the data of hemp stalks taken for analyses before starting dew retting or water retting processes.

In 2006, fibre content in dew retted hemp stalks varied from $11.7 \%$ to $15.0 \%$ in different treatments, and from $11.0 \%$ to $14.7 \%$ in 2007 (Table 5). Although the investigations of Cromack (1998) evidenced that genetic differences (variety) had a greater impact on the content of stem bast fibre than stand density, in our trials in both experimental years neither variety as a factor nor seed rate as a factor showed any significant influence on the dew retted hemp fibre content in hemp stalks.

Statistical evaluation showed that the year as a factor did not affect the dew retted hemp fibre content in hemp stalks; therefore the results averaged over two years are presented in Table 6 . The averaged results of two years evidenced the same - neither variety nor seed rate showed any significant influence on the dew retted hemp fibre content in hemp stalks.

Fibre content in water retted hemp stalks was higher than that of dew retted hemp stalks in 2006 and varied from $18.0 \%$ to $20.3 \%$ in different treatments, but it was rather low in 2007 (because of low water retted straw output in 2007 (Table 6) and lower fibre content in water retted hemp straw (Table 3), and ranged from 9.0\% to $10.7 \%$ (Table 7). Water retted hemp fibre content in hemp stalks was not influenced by variety and seed rate tested.

The processed statistical data showed the influence of the year as a factor, so averaged data from 2006-2007 could not be presented.

Calculation (three-factor analysis) showed that the fibre extraction method as a factor had significant influence on the fibre content in hemp stalks in both experimental years. In 2006, averaged hemp fibre content in hemp stalks was lower $(12.8 \%)$ when applying dew retting method than that when applying water retting (19.2\%), but in 2007 the data were opposite - fibre content was higher (12.4\%) in hemp stalks when applying dew retting and lower $(9.6 \%)$ - in hemp stalks when applying water retting. Some more research needs to be done either to confirm or deny the findings of the current study. 
Table 5. The influence of variety and seed rate on the dew retted hemp fibre content (\%) in the stalks

Upyte Experimental Station, 2006-2007

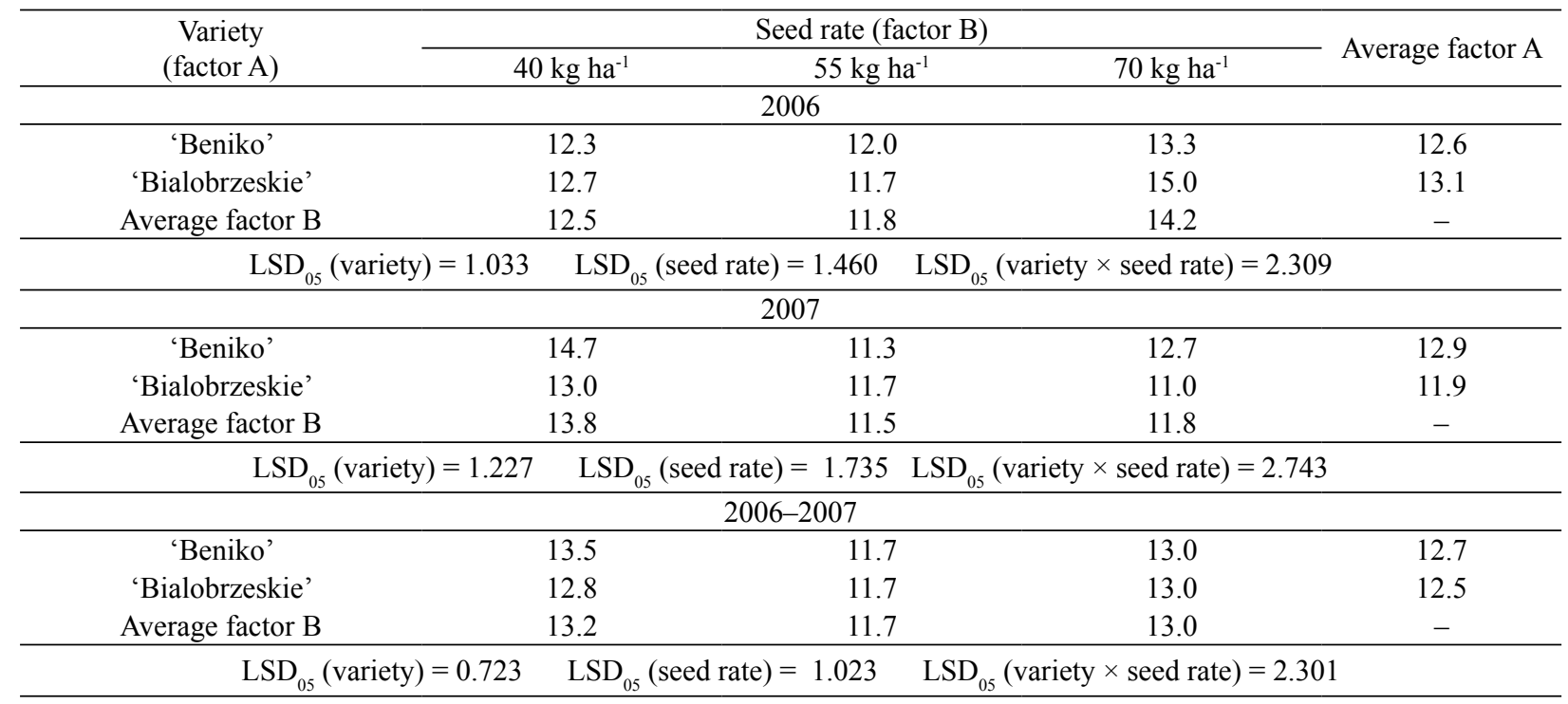

Table 6. The influence of variety and seed rate on the water retted hemp fibre content (\%) in the stalks

Upyte Experimental Station, 2006-2007

\begin{tabular}{|c|c|c|c|c|}
\hline \multirow{2}{*}{$\begin{array}{c}\text { Variety } \\
\text { (factor A) }\end{array}$} & \multicolumn{3}{|c|}{ Seed rate (factor B) } & \multirow{2}{*}{ Average factor $\mathrm{A}$} \\
\hline & $40 \mathrm{~kg} \mathrm{ha}^{-1}$ & $55 \mathrm{~kg} \mathrm{ha}^{-1}$ & $70 \mathrm{~kg} \mathrm{ha}^{-1}$ & \\
\hline \multicolumn{5}{|c|}{2006} \\
\hline 'Beniko’ & 20.3 & 19.7 & 19.7 & 19.9 \\
\hline 'Bialobrzeskie' & 18.0 & 18.3 & 19.0 & 18.4 \\
\hline Average factor B & 19.2 & 19.0 & 19.3 & - \\
\hline \multirow[t]{2}{*}{$\mathrm{LSD}_{05}$} & \multicolumn{2}{|c|}{$\mathrm{LSD}_{05}($ seed rate $)=1.763$} & $\times$ seed rate) & \\
\hline & \multicolumn{2}{|c|}{2007} & & \\
\hline 'Beniko’' & 9.0 & 10.0 & 9.0 & 9.33 \\
\hline 'Bialobrzeskie' & 10.7 & 10.0 & 9.0 & 9.89 \\
\hline Average factor B & 9.8 & 10.0 & 9.0 & - \\
\hline \multicolumn{2}{|c|}{$\mathrm{LSD}_{05}($ variety $)=1.004$} & 1.420 & seed rate) $=$ & \\
\hline
\end{tabular}

Table 7. The influence of variety and seed rate on the dew retted hemp fibre flexibility (mm)

Upyte Experimental Station, 2006-2007

\begin{tabular}{|c|c|c|c|c|}
\hline \multirow{2}{*}{$\begin{array}{c}\text { Variety } \\
\text { (factor A) }\end{array}$} & \multicolumn{3}{|c|}{ Seed rate (factor B) } & \multirow{2}{*}{ Average factor $\mathrm{A}$} \\
\hline & $40 \mathrm{~kg} \mathrm{ha}^{-1}$ & $55 \mathrm{~kg} \mathrm{ha}^{-1}$ & $70 \mathrm{~kg} \mathrm{ha}^{-1}$ & \\
\hline \multicolumn{5}{|c|}{2006} \\
\hline 'Beniko' & 19.4 & 20.8 & 21.3 & 20.5 \\
\hline 'Bialobrzeskie' & 18.2 & 21.0 & 21.0 & 20.1 \\
\hline Average factor B & 18.8 & 20.9 & 21.2 & - \\
\hline \multirow{2}{*}{$\mathrm{LSD}_{05}$ (variety) $=1.530$} & $\mathrm{LSD}_{0}$ & 2.163 & \multicolumn{2}{|c|}{$\mathrm{LSD}_{05}($ variety $\times$ seed rate $)=3.420$} \\
\hline & \multicolumn{4}{|c|}{2007} \\
\hline 'Beniko' & 25.3 & 19.2 & 19.8 & 20.8 \\
\hline 'Bialobrzeskie' & 19.5 & 20.6 & 20.7 & 20.3 \\
\hline Average factor B & 21.5 & 19.9 & 20.2 & - \\
\hline \multicolumn{5}{|c|}{$\mathrm{LSD}_{05}($ variety $)=1.724$} \\
\hline \multicolumn{5}{|c|}{$2006-2007$} \\
\hline 'Beniko' & 21.5 & 20.0 & 20.5 & 20.7 \\
\hline 'Bialobrzeskie' & 18.8 & 20.8 & 20.9 & 20.2 \\
\hline Average factor B & 20.1 & 20.4 & 20.7 & - \\
\hline $\operatorname{LSD}_{05}($ & $\mathrm{LSD}_{05}$ & 1.223 & $\times$ seed rate) & \\
\hline
\end{tabular}


Fibreflexibility. Dew retted hemp fibre flexibility was rather similar in both experimental years. It varied from 18.2 to $21.3 \mathrm{~mm}$ in 2006 and from 19.2 to $25.3 \mathrm{~mm}$ in 2007. Variety as a factor did not exert any significant influence on hemp fibre flexibility - the results were very similar for both varieties. Statistical analysis showed that the year as a factor did not affect dew retted hemp fibre flexibility; therefore the results averaged over two years are presented in Table 7. They show that averaged fibre flexibility for variety 'Beniko' was $20.7 \mathrm{~mm}$, and for variety 'Bialobrzeskie' - $20.2 \mathrm{~mm}$. The trend of higher fibre flexibility (as was expected) at higher sowing rates was noticed over all investigation (except for the case in
2007 for 'Beniko' sown at a seed rate of $40 \mathrm{~kg} \mathrm{ha}^{-1}$ ), but the differences were insignificant.

Water retted hemp fibre flexibility was higher than that of dew retted, and in 2006 varied from 24.3 to $29.9 \mathrm{~mm}$ in different treatments and from 20.4 to 25.5 $\mathrm{mm}$ in 2007 (Table 8). In 2006 and 2007, neither variety nor seed rate showed any significant influence on the water retted hemp fibre flexibility, but a slight trend of more flexible fibre from variety 'Bialobrzeskie' could be observed. Also a tendency of higher fibre flexibility (as was expected) at higher sowing rates was noticed, the differences were insignificant.

Table 8. The influence of variety and seed rate on the water retted hemp fibre flexibility (mm)

Upyte Experimental Station, 2006-2007

\begin{tabular}{|c|c|c|c|c|}
\hline \multirow{2}{*}{$\begin{array}{c}\text { Variety } \\
\text { (factor A) }\end{array}$} & \multicolumn{3}{|c|}{ Seed rate (factor B) } & \multirow{2}{*}{ Average factor A } \\
\hline & $40 \mathrm{~kg} \mathrm{ha}^{-1}$ & $55 \mathrm{~kg} \mathrm{ha}^{-1}$ & $70 \mathrm{~kg} \mathrm{ha}^{-1}$ & \\
\hline \multicolumn{5}{|c|}{2006} \\
\hline 'Beniko' & 24.3 & 24.4 & 27.4 & 25.4 \\
\hline 'Bialobrzeskie' & 27.0 & 29.9 & 27.7 & 28.2 \\
\hline Average factor B & 25.7 & 27.1 & 27.6 & - \\
\hline \multicolumn{5}{|c|}{$\mathrm{LSD}_{05}($ seed rate $)=2.348$} \\
\hline \multicolumn{5}{|c|}{2007} \\
\hline 'Beniko' & 21.7 & 23.7 & 22.7 & 22.7 \\
\hline 'Bialobrzeskie' & 20.4 & 25.5 & 23.8 & 23.2 \\
\hline Average factor B & 21.1 & 24.6 & 23.3 & - \\
\hline $\mathrm{LSD}_{05}$ & $99 \quad \mathrm{LSD}_{0}$ & 1.412 & $x$ seed rate) & \\
\hline
\end{tabular}

Processed statistical data showed the influence of the year as a factor, so averaged data from 2006-2007 could not be presented.

The statistical three-factor analysis showed that the fibre extraction method as a factor had significant influence on hemp fibre flexibility in both experimental years. In 2006, averaged hemp fibre flexibility when applying dew-retting method was significantly lower $(20.3 \mathrm{~mm})$ than that when applying water retting $(26.8$ $\mathrm{mm})$. In 2007, the differences in fibre flexibility were smaller. Hemp fibre flexibility when applying dewretting method was $20.6 \mathrm{~mm}$ and when applying water retting $-23.0 \mathrm{~mm}$.

Fibre strength. In 2006, the strength of fibre obtained from dew retted hemp was approximately twice as low as that in 2007 (Table 9). In 2006, variety as a factor showed significant influence on the strength of fibre obtained from dew retted hemp - fibre of variety
'Beniko' was less firm $(5.1 \mathrm{~kg} \mathrm{~F})$ than that of variety 'Bialobrzeskie' (6.2 kg F). In 2007, the same trend persisted, but the differences were not significant. In our trials, seed rate as a factor did not show any significant influence on the dew retted hemp fibre strength. Some literature sources report, that the highest strength of homomorphic fibre $\left(33.8 \mathrm{CN}^{-1} \mathrm{x}^{-1}\right)$ was obtained at the lowest sowing density, $60 \mathrm{~kg}$ of seeds per ha (when testing seed rates of 60, 90 and $120 \mathrm{~kg} \mathrm{ha}^{-1}$ ) (Mańkowski, 2003). Our selected seed rates were lower, but the strongest fibre was obtained also at seed rates of 55 and $70 \mathrm{~kg} \mathrm{ha}^{-1}$.

Statistical evaluation confirmed that the year as a factor affected the dew retted hemp fibre strength (the average hemp fibre strength after dew-retting in 2006 was only $5.7 \mathrm{~kg} \mathrm{~F}$ and in $2007-13.4 \mathrm{~mm}$ ), therefore the results averaged over two years cannot be presented.

The results of our investigation show, that the strength of fibre obtained after hemp water retting was very

Table 9. The influence of variety and seed rate on the dew retted hemp fibre strength (kg F)

Upytė Experimental Station, 2006-2007

\begin{tabular}{|c|c|c|c|c|}
\hline \multirow{2}{*}{$\begin{array}{c}\text { Variety } \\
\text { (factor A) }\end{array}$} & \multicolumn{3}{|c|}{ Seed rate (factor B) } & \multirow{2}{*}{ Average factor A } \\
\hline & $40 \mathrm{~kg} \mathrm{ha}^{-1}$ & $55 \mathrm{~kg} \mathrm{ha}^{-1}$ & $70 \mathrm{~kg} \mathrm{ha}^{-1}$ & \\
\hline \multicolumn{5}{|c|}{2006} \\
\hline 'Beniko' & 5.0 & 4.7 & 5.6 & $5.1^{*}$ \\
\hline 'Bialobrzeskie' & 6.5 & 6.7 & 5.5 & $6.2 *$ \\
\hline Average factor B & 5.8 & 5.7 & 5.6 & - \\
\hline \multicolumn{5}{|c|}{$\mathrm{LSD}_{05}($ seed rate $)=0.611$} \\
\hline \multicolumn{5}{|c|}{2007} \\
\hline 'Beniko' & 12.1 & 15.4 & 12.6 & 13.4 \\
\hline 'Bialobrzeskie' & 13.4 & 15.3 & 11.9 & 13.5 \\
\hline Average factor B & 12.7 & 15.3 & 12.2 & - \\
\hline \multicolumn{5}{|c|}{$\operatorname{LSD}_{05}$ (variety) $=1.836 \quad$ LSD } \\
\hline
\end{tabular}


close to that of dew retted hemp straw and varied from 4.3 to $6.0 \mathrm{~kg} \mathrm{~F}$ in different treatments in 2006 and from 12.5 to $14.2 \mathrm{~kg} \mathrm{~F}$ in 2007 (Table 10). In 2006, the strength of fibre obtained from water retted hemp was approximately twice as low as that in 2007. This means that the year as a factor had an influence on fibre strength.

Table 10. The influence of variety and seed rate on the water retted hemp fibre strength $(\mathrm{kg} \mathrm{F})$

Upyte Experimental Station, 2006-2007

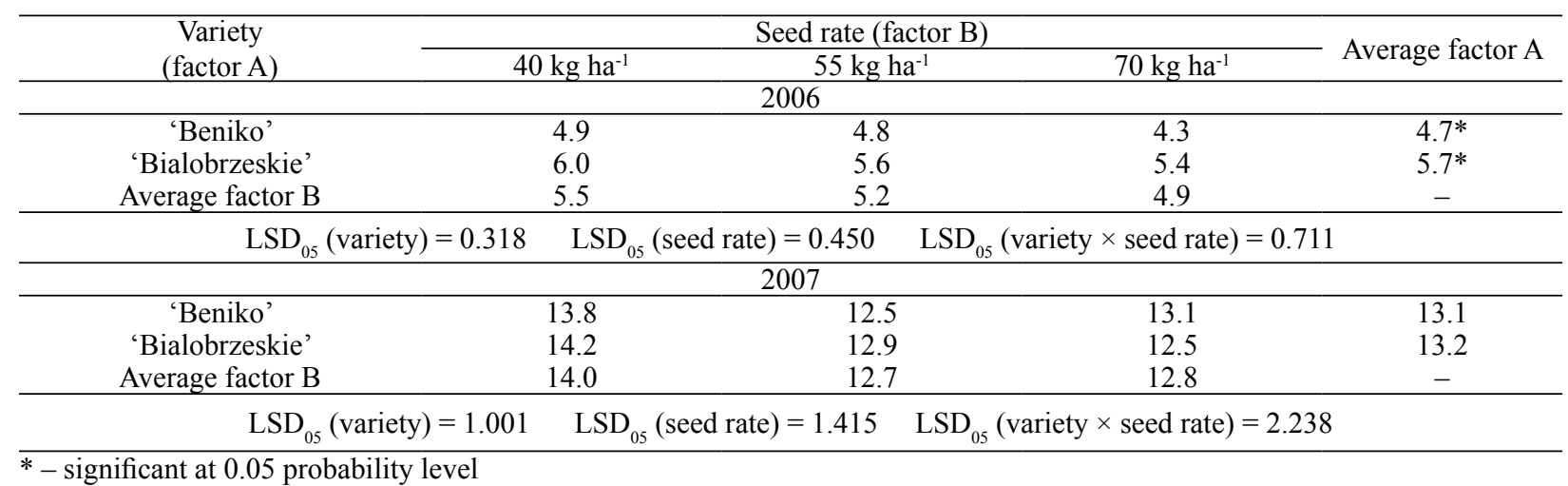

In 2006, variety as a factor had a significant influence on the strength of fibre obtained from water retted hemp. In 2007, the same trend persisted, but the differences were very small and not significant. Seed rate as a factor did not show any significant influence on the water retted hemp fibre strength, but a trend of lower fibre strength at higher sowing rates was noticed.

Statistical evaluation confirmed that the year as a factor affected the water retted hemp fibre strength (the average hemp fibre strength after water retting in 2006 was only $5.2 \mathrm{~kg} \mathrm{~F}$ and in $2007-13.2 \mathrm{~kg} \mathrm{~F}$ ), so the results averaged over 2006-2007 cannot be presented.

Calculation (three-factor analysis) showed that fibre extraction method as a factor also had significant influence on the hemp fibre strength in 2006 (in 2007 the influence was very small and not significant). Although the means were rather close $(4.9 \mathrm{~kg} F$ for dew retted fibre and $6.0 \mathrm{~kg} \mathrm{~F}$ for water retted fibre), the differences were found to be significant.

\section{Conclusions}

1. The seed rate as a factor did not show any significant influence on physical hemp fibre parameters. Some trends of higher parameters at higher seed rates were observed: the trend of insignificantly higher fibre content at higher seed rates; the trend of lower fibre strength at higher sowing rates. The trend of higher fibre flexibility (as was expected) at higher sowing rates was noted throughout the study.

2. The variety as a factor exerted a higher impact on physical hemp fibre parameters (fibre content in dew retted and water retted hemp straw, and dew retted hemp straw output from hemp stalks). The variety as a factor influenced the strength of fibre obtained from dew retted and water retted hemp (in 2006, the influence was significant, and in 2007 - not significant).

3. The year as a factor affected the majority of physical parameters tested, except for the dew retted hemp fibre content in hemp stalks and dew retted hemp fibre flexibility.

4. The fibre extraction method as a factor also had a significant influence on the hemp fibre content in the straw in 2006, on the hemp straw output from the stalks in 2007, on the fibre content in hemp stalks, and on the hemp fibre flexibility in both experimental years, on the hemp fibre strength in 2006.

5. The dew retted and water retted hemp fibres differed in appearance. After dew-retting, the fibre was not very homogenous, light-grey and dark-grey, contained some dark spots (the residues of dew retting fungus), and included some impurities (woody parts of stem). After water retting, hemp fibre also was not very homogenous, was light-grey and looked softer and more decomposed.

\section{Acknowledgments}

The study was supported by the Lithuanian Ministry of Agriculture. Project "The preparation of growing and harvesting technologies for industrial hemp (Cannabis sativa)", contract No. 8P-393, 25082006.

Received 26032012

Accepted 10102012

\section{References}

Akin D. E., Foulk J. A., Dodd R. B., McAlister III D. D. 2001. Enzyme-retting of flax and characterization of processed fibers. Journal of Biotechnology, 89: 193-203 http://dx.doi.org/10.1016/S0168-1656(01)00298-X

Amaducci S., Medeghini Bonatti P., Pelatti F. 2005. Fibre development in hemp (Cannabis sativa L.) as affected by agrotechnique: preliminary results of a microscopic study. Journal of Industrial Hemp, 10 (1): 31-48 http://dx.doi.org/10.1300/J237v10n01 04

Barron A., Coutinho J., English A., Gergely S., Lidouren E. 2003. Integrating hemp in organic farming systems - a focus on the United Kingdom, France and Denmark. $<$ http://northcoasthemp.wholistic.com.au/wp-content/ uploads/2008/08/integrating-hemp-in-organic-farmingsystems.pdf $>$ [accessed 26032012 ]

Bengtsson E. 2009. Obtaining high quality textile fibre from industrial hemp through organic cultivation. Individual Project at the LTJ Faculty, SLU, Alnarp, The Horticultural Programme 2009-03, 15 ECTS, level C. Alnarp, Sweden, 40 p.

Bócsa I. 1999. Genetic improvement: Conventional approaches. Advances in hemp research / Ranalli P. (ed.) New York, USA, p. 153-184

Bócsa I., Karus M. 1998. Hemp cultivation. The cultivation of hemp: botany, varieties, cultivation and harvesting. Sebastopol, USA, p. 72-102

Buivydaitè V. V., Vaičys M., Juodis J., Motuzas A. 2001. Lietuvos dirvožemių klasifikacija. Vilnius, p. 76 (in Lithuanian)

Cromack H. T. H. 1998. The effect of cultivar and seed density on the production and fibre content of Cannabis sativa in southern England. Industrial Crops and Products, 7 (2): 205-210

http://dx.doi.org/10.1016/S0926-6690(97)00049-6

Daenekindt A. 2004. Flax, hemp and allied fibres in the world. Euroflax Newsletter, 21: 6-9 
Donaghy J. A., Levette P. N., Haylock R. W. 1990. Changes in microbial populations during anaerobic flax retting. Journal of Annlied Bacteriology, 69: 634-641 http://dx.doi.org/10.1111/j.1365-2672.1990.tb01556.x

Garcia-Jaldon C., Dupeyre D., Vignon M. R. 1998. Fibres from semi-retted hemp bundles by steam explosion treatment. Biomass and Bioenergy, 14: 251-260 http://dx.doi.org/10.1016/S0961-9534(97)10039-3

Grabovska L., Koziara W. 2005. The effect of nitrogen dose, sowing density and time of harvest on development and yields of hemp cultivar 'Bialobrzeskie'. Journal of Natural Fibres. 2 (4): 1-17 http://dx.doi.org/10.1300/J395v02n04 01

Henriksson G., Akin D. E., Hanlin R. T., Rodriguez C., Archibald D. D., Rigsby L. L., Eriksson K. L. 1997. Identification and retting efficiency of fungi isolated from dew retted flax in the United States and Europe. Applied and Environmental Microbiology, 63 (10): 3950-3956

Hoffmann W. 1961. Hanf. Cannabis sativa L. V. Handbuch der Pflanzenz chtung / Kappert H., Rudorf W. (eds). Berlin, Germany, p. 204-261

Mańkowski J. 2003. The effect of some agronomic factors on the amount and quality of homomorphic fibre. Fibres and Textiles in Eastern Europe, 11 (4): 43

Mwaikambo L. Y. 2006. Review of the history, properties and application of plant fibres. African Journal of Science and Technology, 7 (2): 120-133

Sankari H. S. 2000. Comparison of bast fibre yield and mechanical fibre properties of hemp (Cannabis sativa L.) cultivars. Industrial Crops and Products, 11: 73-84 http://dx.doi.org/10.1016/S0926-6690(99)00038-2

Sharma H. S. S. 1987. Studies on chemical and enzyme retting of flax on a semi-industrial scale and analysis of the effluents for their physicochemical components. International Biodeterioration, 23 (6): 329-342 http://dx.doi.org/10.1016/0265-3036(87)90022-4

Small E., Marcus D. 2002. Hemp: a new crop with new uses for North America. Trends in new crops and new uses / Janick J., Whipkey A. (eds). Alexandria, USA, p. 284-326
Struik P. C., Amaducci S., Bullard M. J., Stutterheim N. C., Venturi G., Cromack H. T. H. 2000. Agronomy of fibre hemp (Cannabis sativa L.) in Europe. Industrial Crops and Products. 11: 107-118

http://dx.doi.org/10.1016/S0926-6690(99)00048-5

Svennerstedt B. 2002. Hemp, growth, seed rate, biomass and hemp fibre yield. Production, processing and use of natural fibres. Potsdam, Germany, p. 28

Tarakanovas P., Raudonius S. 2003. Agronominių tyrimų duomenų statistinè analizè taikant kompiuterines programas ANOVA, STAT, SPLIT-PLOT iš paketo SELEKCIJA ir IRRISTAT. Akademija, Kauno r. 58 p. (in Lithuanian)

Thygesen A., Daniel G., Lilhot H., Thomsen A. B. 2005. Hemp fiber microstructure and use of fungal defibration to obtain fibers from composite materials. Journal of Natural Fibres, 2(4): $19-37$

http://dx.doi.org/10.1300/J395v02n04_02

Van der Werf H. M. G., Harsveld van der Veen J. E., Bouma A. T. M., ten Cate M. 1994. Quality of hemp (Cannabis sativa L.) stems as a raw material for paper. Industrial Crops and Products. 2: 219-227 http://dx.doi.org/10.1016/0926-6690(94)90039-6

Van der Werf H. M. G., van Geel W. C. A., Wijlhuizen M. 1995. Agronomic research on hemp (Cannabis sativa L.) in the Netherlands, 1987-1993. <http://www. internationalhempassociation.org/jiha/iha02107.html $>$ [accessed 1603 2012]

Van Sumare C. 1992. Retting of flax with special reference to enzyme-retting. The biology and processing of flax / Sharma H., Van Sumare C. (eds). Belfast, Northern Ireland, p. $157-198$

Xu J. 2010. Analysis and design of hemp fibre decorticators: a thesis, University of Manitoba. Winnipeg, Canada, $100 \mathrm{p}$.

Zhang L. L., Zhu R. Y., Chen J. Y., Chen J. M., Feng X. X. 2008. Seawater-retting treatment of hemp and characterization of bacterial strains involved in the retting process. Process Biochemistry. 43: 1195-1201 http://dx.doi.org/10.1016/j.procbio.2008.06.019

Методики технологической оценки льни и конопли. 1961. Moscow, Russia, 182 c. (in Russian)

ISSN 1392-3196

Zemdirbyste-Agriculture, vol. 100, No. 1 (2013), p. 71-80

UDK 633.5:631.531:631.526.32 / DOI 10.13080/z-a.2013.100.010

\section{Sėjamosios kanapès (Cannabis sativa L.) klojèto ir mirkyto pluošto fizikiniai rodikliai}

\section{Z. Jankauskienè, E. Gruzdevienė}

Lietuvos agrarinių ir miškų mokslų centro Upytės bandymų stotis

\section{Santrauka}

Net nedideli sejjamosios kanapės pluošto priedai audiniams suteikia didesnị paviršinị atsparumą, padidina šilumos sugėrimą, o tai leidžia žmogaus kūnui lengviau prisitaikyti prie kintančių aplinkos sąlygų. Greta ịvairių ịmanomų pluošto išgavimo iš kanapių stiebų būdų dažniausiai naudojami du - stiebų klojejjimas ir mirkymas. Abiem būdais gauto pluošto kokybė yra nevienoda.

Lietuvos žemdirbystès instituto Upytès bandymų stotyje 2006-2007 m. atliktų tyrimų duomenimis, klojètų ir mirkytų kanapių pluošto išvaizda buvo nevienoda. Nustatyta veislès kaip veiksnio įtaka kanapių pluošto fizikiniams rodikliams: pluošto išeigai iš klojètų ir mirkytų kanapių šiaudelių, klojètų šiaudelių išeigai iš stiebų, 2006 m. esminè įtaka klojètų ir mirkytų kanapių pluošto stiprumui (2007 m. pastebèta tokia pat tendencija). Sèklos normos kaip veiksnio esminès įtakos kanapių fizikiniams rodikliams tyrimų metu nenustatyta, tačiau pastebètos kai kurios geresnių rodiklių, sejjant pagal didesnes sẻklos normas, tendencijos: $2006 \mathrm{~m}$. šiek tiek didesnè pluošto išeiga, didesnis pluošto lankstumas (to ir buvo tikètasi vykdant bandymus). Statistinis duomenų įvertinimas parodè, jog ir metai kaip veiksnys turèjo įtakos daugeliui klojètų bei mirkytų kanapių fizikinių rodiklių, išskyrus klojètų kanapių pluošto išeigą iš stiebų ir pluošto lankstumą. Statistinè duomenų analizè parodè, kad pluošto išgavimo būdas (klojèjimas ar mirkymas) taip pat turèjo esminès itakos pluošto išeigai iš šiaudelių 2006 m., šiaudelių išeigai iš stiebelių - 2007 m., pluošto išeigai iš stiebelių - abiem tyrimų metais, pluošto stiprumui - $2006 \mathrm{~m}$.

Reikšminiai žodžiai: Cannabis sativa, fizikiniai rodikliai, klojèjimas, mirkymas, pluoštas, sèklos norma, veislès. 